\title{
Analisis Jejas Gigitan pada Kasus Forensik Klinik
}

\section{Erwin Kristanto}

\author{
Bagian Kedokteran Forensik dan Medikolegal Fakultas Kedokteran Universitas Sam \\ Ratulangi \\ Email: erwinkristanto@unsrat.ac.id
}

\begin{abstract}
Examination of bite mark is one form of dental assistance for the enforcement of justice. A dentist can examine bite mark or be asked his/her expert assessment of bite mark that has been recorded by another dentist. The source of bite marks, the substrate onto which they are generated, and the technique of lifting the bite imprints serve as important tools in analysis. This study was aimed to obtain how accurate the bite-mark analysis could reveal the prepetrator. This was a retrospective and descriptive study, using clinical forensic data from RS Bhayangkara Tingkat III in Manado from January 2015 to December 2019. This study used 2,197 clinical forensic cases data, of which there were 34 cases with bite marks.The most common bite sites were found in the arms $(23.4 \%)$ and the least locations were found on the cheeks and neck $(0.2 \%)$. There were $85.29 \%$ of bite marks that could be matched with suspected tooth molds. In conclusion, as many as $85.29 \%$ of bite marks in this study could be matched with suspected tooth molds. Albeit, mismatch of tooth patterns is not automatically removed somebody from the suspect list. Determinant variables such as the location of bite mark, movement of the jaw or part of the body bitten, and the process of inflammation in the body of the victim must be used as material for analysis in identifying the perpetrators.
\end{abstract}

Keywords: bite mark, forensic odontology, identification of suspect

\begin{abstract}
Abstrak: Pemeriksaan jejas gigi (bite mark) merupakan salah satu bentuk bantuan dokter gigi bagi penegakan keadilan. Seorang dokter gigi dapat diminta melakukan pemeriksaan dan analisis jejas gigi atau diminta untuk memberikan keterangan ahli tentang jejas gigi yang telah diperoleh dokter gigi lain. Sumber bekas gigitan, media yang digunakan untuk mendokumentasikan dan teknik mentransfer bekas gigitan berfungsi sebagai alat penting dalam analisis. Penelitian ini bertujuan untuk mengetahui seberapa besar analisis jejas gigitan dapat mengungkapkan pelaku. Jenis penelitian ini ialah deskriptif retrospektif, menggunakan data forensik klinik dari RS Bhayangkara tingkat III Manado pada rentang tahun 2015-2019. Pada penelitian ini digunakan data dari 2197 kasus forensik klinik; di antaranya terdapat 34 kasus dengan jejas gigitan (bite mark). Lokasi jejas gigitan terbanyak ditemukan pada lengan $(23,4 \%)$ dan paling sedikit pada pipi dan leher, $(0,2 \%)$ serta didapatkan $85,29 \%$ jejas gigitan pada penelitian ini dapat dicocokkan dengan cetakan gigi tersangka. Simpulan penelitian ini ialah sebesar 85,2\% jejas gigitan dapat mengungkapkan pelaku, namun ketidakcocokan pola gigi tidak secara otomatis menyingkirkan seseorang dari daftar tersangka. Variabel penentu seperti lokasi gigitan, pergerakan rahang atau bagian tubuh yang digigit, dan proses peradangan pada tubuh korban harus dijadikan bahan analisis dalam mengidentifikasi pelaku, agar tidak terjadi kesalahan identifikasi pelaku.
\end{abstract}

Kata kunci: jejas gigitan, odontologi forensik, identifikasi pelaku

\section{PENDAHULUAN}

Seperti halnya dokter, dalam melaksanakan tugas dan kompetensinya, dokter gigi tidak jarang dimintai bantuan dalam proses penegakan keadilan, terutama terkait bidang keahliannya di bidang kedokteran gigi. Dokter gigi pada kondisi ini melakukan perannya sebagai dokter penilai 
(assessing doctor), yang membantu penyidik atau aparat penegak hukum lain melalui: identifikasi mayat yang tidak dikenal melalui gigi, rahang, dan kraniofasial; penentuan umur gigi; pemeriksaan jejas gigi (bite mark); penentuan ras; analisis trauma orofasial yang berkaitan dengan tindakan kekerasan; memberikan keterangan ahli/saksi ahli; dan melakukan pengumpulan sampel DNA dari bahan gigi dalam penentuan identitas seseorang. ${ }^{1}$

Identifikasi menggunakan gigi bukanlah teknik yang baru. Teknik ini dapat dilacak hingga tahun 66 setelah Masehi yaitu pada jaman kaisar Nero dari Roma. Di Indonesia walau sebelum tahun 1980 jumlahnya masih sedikit, namun jumlah kasusnya makin bertambah seiring dengan kemajuan perkembangan ilmu pengetahuan saat ini. ${ }^{2}$ Penelitian ini menggabungkan analisis jejas gigitan (bite mark analysis) dengan proses membandingkan jejas gigitan (bite mark comparison) yang dalam tulisan ini hanya disebut sebagai analisis jejas gigitan.

Analisis jejas gigitan ialah bagian dari proses autopsi medikolegal dan merupakan proses dokumentasi objektif dan interpretasi bukti seputar jejas berpola yang mungkin jejas gigitan atau bukan jejas gigitan. Analisis ini tidak mencakup proses membandingkan dengan pola gigi tersangka atau identifikasi tersangka atau asosiasi dengan pola gigi kelompok tertentu. Pembandingan jejas gigitan merupakan proses dengan berbagai metode untuk membandingkan pola gigi dengan maksud untuk mengeliminasi kemungkinan seseorang merupakan pelaku dari suatu peristiwa. ${ }^{3}$ Walaupun kedua proses merupakan proses yang berbeda, namun karena pelaksanaannya dilakukan secara terintegrasi di RS Bhayangkara, maka pada tulisan ini kedua terminologi disatukan untuk kepentingan pengambilan simpulan penelitian.

Jejas gigitan merupakan suatu bentuk jejas berpola yang diakibatkan oleh gigi dengan konfigurasi gigi pelaku, atau dapat terjadi pola kombinasi antara pola gigi dengan benda lain pada gigi atau rongga mulut. Jejas gigitan dapat ditemukan pada seseorang yang masih hidup atau yang telah meninggal, dimana orang tersebut mungkin merupakan korban kejahatan atau pelaku kejahatan. Selain itu, jejas gigitan juga dapat ditemukan pada makanan atau benda lain di tempat kejadian perkara. Jejas gigitan dapat terbentuk saat terjadinya penyerangan pada seseorang, atau tindakan yang berhubungan dengan kekerasan seksual. ${ }^{4}$

Jejas gigitan harus diperiksa dan mungkin ditemukan pada hampir seluruh permukaan tubuh. Jejas gigi pada tempat yang spesifik dapat membantu untuk mengasosiasikan jejas dengan jenis motif kejahatan tertentu. Jejas gigitan pada leher, payudara, dan pundak dapat diasosiasikan dengan serangan yang bermotif seksual, sedangkan untuk kasus kekerasan pada anak, jejas gigitan sering ditemukan pada lengan dan pantat. Jejas gigitan yang dibuat sendiri (self-inflicted) paling sering ditemukan pada bagian medial dari lengan. ${ }^{5}$

Seorang dokter gigi, terlebih dokter gigi forensik, dapat memperoleh data yang banyak tentang gigi seseorang dari jejas gigitan. Bila pada jejas gigitan tampak terdapat gap, maka kemungkinan ada gigi pelaku yang telah tercabut atau tidak ada. Gigi yang memiliki susunan tidak rata akan membentuk jejas gigitan yang tidak rata, dan gigi yang patah akan meninggalkan jejas gigitan yang bergerigi dengan kedalaman jejas yang bervariasi. Pelaku yang menggunakan kawat gigi saat menggigit juga akan memberi gambaran impresi jejas yang khas. ${ }^{5}$

\section{METODE PENELITIAN}

Penelitian ini dilaksanakan di RS Bhayangkara tingkat III Manado, dengan cara mengumpulkan data rekam medis pasien di unit rekam medis. Data rekam medis yang diambil yaitu data rekam medis pemeriksaan forensik klinik dari bulan Januari tahun 2015 sampai bulan Desember tahun 2019. Data yang diinklusikan pada penelitian ini ialah kasus yang disertai permintaan penyidik atau penyidik pembantu dari kantor kepolisian. 
Penelitian ini merupakan penelitian deskriptif analitik yang mengumpulkan data kasus dengan jejas gigi (bite mark). Penulis melalui RS Bhayangkara tingkat III Manado juga berkomunikasi dengan penyidik untuk memperoleh informasi tambahan terkait identifikasi pelaku dan jalannya proses penyidikan.

Data yang dikompilasi dari rekam medis berupa pemeriksaan forensik, foto, dan hasil pemeriksaan penunjang, ditampilkan dalam bentuk gambar, tabel, dan grafik. Dokumentasi bite mark dilakukan dengan dokumentasi fotografi atau transfer ke kertas transparan atau lembaran asetat. Data hasil kompilasi digunakan untuk diskusi dan menarik simpulan penelitian.

Penelitian ini telah mendapat persetujuan dari komisi etik RSUP Prof. Dr. R. D. Kandou Manado, dengan nomor keterangan layak etik yaitu No. 123/EC/KEPKKANDOU/XII/2019.

\section{HASIL PENELITIAN}

Gambar 1 memperlihatkan grafik jumlah kasus forensik klinik di RS Bhayangkara Tingkat III Manado tahun 20152019. Terdapat tren peningkatan jumlah kasus forensik klinik setiap tahunnya.

Tabel 1 memperlihatkan kasus forensik klinik di RS Bhayangkara tingkat III Manado didominasi oleh kasus kecelakaan lalu lintas dan kecelakaan kerja, serta penganiayaan dan kekerasan dalam rumah tangga.

Gambar 2 memperlihatkan grafik jumlah kasus dengan jejas gigitan tahun 20152019. Terdapat penurunan jumlah kasus pada tahun 2017, kemudian meningkat lagi di tahun berikutnya.

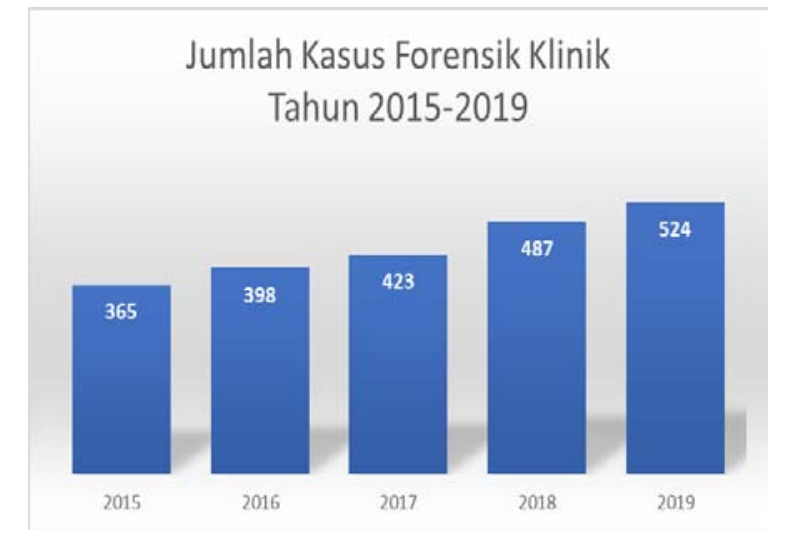

Gambar1. Grafik jumlah kasus forensik klinik di RS Bhayangkara Tingkat III Manado tahun 2015-2019

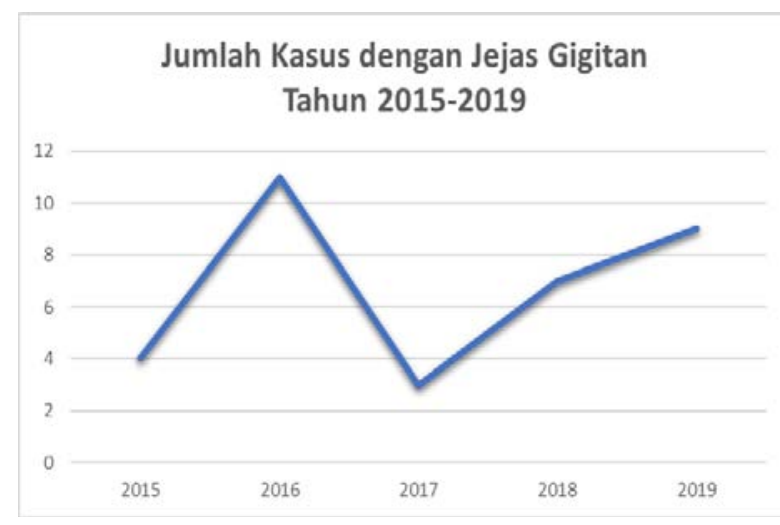

Gambar2. Kasus dengan jejas gigitan di RS Bhayangkara Tingkat III Manado tahun 20152019

Tabel 2 memperlihatkan jumlah total jejas gigitan yang lebih besar dibandingkan jumlah total kasus forensik klinik yang tercatat pada Gambar 2; hal ini disebabkan karena adanya kasus-kasus dengan beberapa lokasi jejas gigitan pada 1 kasus.

Tabel 1. Jumlah kasus forensik klinik berdasarkan jenis kasus di RS Bhayangkara Tingkat III Manado periode Januari 2015 - Desember 2019

\begin{tabular}{lccccc}
\hline \multicolumn{1}{c}{ Jenis kasus } & \multicolumn{5}{c}{ Jumlah } \\
& 2015 & 2016 & 2017 & 2018 & 2019 \\
\hline Kecelakaan lalu-lintas dan kecelakaan kerja & 113 & 142 & 151 & 207 & 223 \\
Percabulan dan kekerasan seksual & 90 & 93 & 96 & 112 & 129 \\
Penganiayaan dan kekerasan dalam rumah tangga & 162 & 163 & 176 & 168 & 172 \\
Total & 365 & 398 & 423 & 487 & 524 \\
\hline
\end{tabular}


Tabel 2. Lokasi jejas gigitan pada kasus forensik klinik di RS Bhayangkara Tingkat III Manado tahun 2015-2019

\begin{tabular}{clc}
\hline No & Lokasi jejas & Jumlah \\
\hline 1 & Pipi & 1 \\
2 & Telinga & 2 \\
3 & Leher & 1 \\
4 & Pundak & 7 \\
5 & Dada & 5 \\
6 & Payudara & 6 \\
7 & Pantat & 3 \\
8 & Lengan & 11 \\
9 & Tungkai & 9 \\
\hline
\end{tabular}

Berbeda dengan pola yang lazim, pada penelitian ini terdapat gigitan pada payudara dan pundak yang terjadi saat perkelahian dan tidak terdapat motif seksual. Jejas terjadi pada kedua belah pihak yang berkelahi dan dikuatkan dengan bukti video amatir yang direkam oleh saksi yang hadir di tempat kejadian perkara.

Pada 34 kasus dengan jejas gigitan, dibuat cetakan gigi dari jejas gigitan, dan pada proses penyidikan dibuatkan cetakan gigi dari tersangka melalui bantuan dokter gigi RS Bhayangkara tingkat III Manado. Pada kasus-kasus ini terdapat 29 cetakan jejas gigitan $(85,29 \%)$ yang cocok dengan cetakan gigi tersangka.

\section{BAHASAN}

Rumah sakit Bhayangkara tingkat III Manado merupakan rumah sakit tipe C milik Kepolisian Republik Indonesia dengan pola pengelolaan keuangan badan layanan umum (BLU) dan telah terakreditasi paripurna oleh komisi akreditasi rumah sakit sejak tahun 2017. RS Bhayangkara memiliki 434 tempat tidur dengan layanan kedokteran forensik dan medikolegal sebagai layanan khas sesuai matra RS milik POLRI. ${ }^{6}$

Rumah sakit Bhayangkara tingkat III Manado memiliki kasus forensik klinik yang cukup banyak dengan trend meningkat setiap tahunnya (Gambar 1). Jaminan kesehatan yang umumnya tidak menanggung biaya pemeriksaan untuk kepentingan hukum mendorong kantor kepolisian yang mengurus kasus, mengantarkan korban untuk diperiksa ke RS Bhayangkara Tingkat III karena adanya bantuan pertanggungan biaya pemeriksaan dari dana bidang kedokteran kepolisian.

Dari seluruh kasus forensik klinik yang diperiksa di RS Bhayangkara tingkat III Manado, setiap tahunnya terdapat kasus dengan jejas gigitan, dengan total 34 kasus yang terjadi pada rentang tahun 2015-2019 (Gambar 2). Penanganan kasus dengan jejas gigitan di RS Bhayangkara melibatkan dokter gigi yang bertugas di RS Bhayangkara, termasuk dalam pencatatan jejas dan pencetakan model gigi dari jejas dan tersangka. Hasil penelitian ini tidak mencantumkan kasus jejas gigitan yang ditemukan pada korban meninggal dunia (kasus patologi forensik).

Pemeriksaan jejas dan proses pencocokannya dengan pola gigi tersangka membutuhkan kerjasama dari seorang dokter ahli forensik dan dokter gigi forensik. Pemeriksaan tubuh korban, termasuk pencatatan jejas gigitan dilakukan oleh dokter ahli forensik dan pencetakan gigi dari jejas atau tersangka dilakukan oleh dokter gigi forensik. Dokter ahli forensik dan dokter gigi forensik dalam melaksanakan tugasnya harus memahami prosedur yang memastikan utuhnya rantai barang bukti.

Jejas gigitan manusia biasanya berbentuk semi sirkular atau kresentik yang disebabkan tekanan bagian depan gigi (incicivus dan caninus), dengan gap pada kedua sisinya karena terpisahnya rahang atas dan rahang bawah. Gigi dapat membentuk jejas yang terpisah atau membentuk jejas garis kontinu atau bias, juga garis intermiten. Dari sisi jenis jejas, jejas gigitan dapat membentuk jejas abrasi, kontusi atau luka terbuka, atau bahkan kombinasi dari dua atau ketiganya.

Pada saat seseorang menggigit sesuatu, gigi pada rahang atas berfungsi untuk menstabilisasi objek yang akan digigit, sementara gigi pada rahang bawah akan berusaha untuk melakukan tekanan untuk memotong objek tersebut. Indentasi yang 
dihasilkan gigi pada rahang atas amat penting dalam memperoleh informasi seperti pola jajaran gigi (dental alignment), ukuran gigi, dan bentuk gigi. ${ }^{8}$

Pemeriksaan pada kasus jejas gigitan (bite mark) sebaiknya sesegera mungkin dilakukan, karena jejas gigitan ini akan berubah seiring berjalannya waktu, baik karena proses peradangan maupun proses lain pada tubuh. Impresi dari jejas gigitan pada kulit yang tidak menyebabkan luka/diskontinuitas kulit dapat menghilang mulai dari beberapa menit sampai 24 jam, tergantung kekuatan penekanan rahang pada kulit. ${ }^{9}$ Memar di sekitar jejas gigitan dapat timbul 4 jam setelah terbentuk jejas gigitan dan menghilang setelah 36 jam pasca gigitan. Jejas gigitan sebaiknya diproses sebelum 24 jam pertama sejak jejas terjadi, dan dokter gigi dapat meminta korban datang kembali untuk proses pemeriksaan ulangan bila diperlukan. Proses yang perlu segera dilakukan yaitu swab pada jejas gigitan, dilakukan pengambilan foto sesuai kaidah fotografi forensik, dan bila perlu dilakukan pencetakan bekas gigitan. $^{10,11}$

Langkah pertama dalam melakukan analisis jejas gigitan ialah mengidentifikasi jejas apakah jejas tersebut ditimbulkan oleh manusia atau binatang. Jejas gigi binatang akan memberi pola yang amat berbeda dengan gigi manusia karena anatominya yang berbeda. Dokter gigi selanjutnya akan mengukur masing-masing jejas gigi dan mencatatnya ke dalam odontogram. Langkah berikutnya ialah melakukan analisis apakah jejas gigitan tersebut dibuat sendiri (self inflicted) atau oleh manusia lain. ${ }^{8,10}$

Jejas gigitan yang ditemukan pada kasus forensik klinik di RS Bhayangkara Manado didokumentasikan dengan foto digital pada saat pemeriksaan dan 36 jam setelah terjadinya jejas gigitan. Foto dilakukan oleh orang yang sama, dengan kamera, serta setting kamera dan filter yang sama. Pengambilan foto berulang ini dimaksudkan untuk memperoleh data bila terjadi perubahan jejas gigitan akibat proses peradangan, infeksi, atau proses lain pada tubuh. $^{9}$ Dokumentasi foto ini melengkapi data odontogram yang ada di rekam medis rumah sakit.

Pada penelitian ini didapatkan 29 cetakan jejas gigitan $(85,29 \%)$ yang cocok dengan cetakan gigi tersangka. Penelitian oleh Sacks et $\mathrm{al}^{12}$ menunjukkan kecocokan jejas gigitan dapat mencapai $90 \%$ dengan persyaratan bahwa jejas gigitan yang diperiksa memberi impresi gigi yang jelas. Sacks juga memberikan syarat tambahan bahwa jejas gigitan dianalisis oleh lebih dari 1 ahli gigi forensik untuk menghindari hasil "false positive" atau "false negative". Blackwel et $\mathrm{al}^{13}$ memperkuat kegunaan jejas gigitan dalam penelitiannya menggunakan 42 sampel kasus yang mampu memberi nilai kecocokan hingga $85 \%$ dengan menggunakan metode pencitraan 3 dimensi pada pola jejas gigitan dan cetakan gigi tersangka.

Hasil ini selaras dengan penelitian yang dilakukan Daniel dan Pazhani tahun 2015 yang menunjukkan kecocokan jejas gigitan pada bahan makanan dengan cetakan gigi pelaku mencapai angka 84\%92\% tergantung jenis makanan dan sifat bahan makanan tersebut. Penelitian ini menguatkan pentingnya bite mark digunakan sebagai petunjuk dalam menemukan tersangka, dan penelitian ini menekankan pentingnya pengumpulan bekas gigitan dari bahan makanan yang ada di tempat kejadian perkara. Jejas gigitan pada bahan makanan juga dapat mempertajam hasil analisis jejas gigitan pada kulit karena dapat memberikan gambaran impresi gigi yang tiga dimensi. ${ }^{14}$

\section{Kesulitan dan Tantangan}

Kesulitan yang paling sering dialami seorang dokter gigi dalam analisa jejas gigitan yaitu memastikan akurasi dari cetakan gigi yang dibuat. Cetakan yang terbentuk akibat tekanan gigi mungkin dapat menurun akurasinya karena permukaan tubuh yang ireguler. Pembuatan cetakan (imprint) di daerah permukaan dengan lekuk tubuh seperti pergelangan tangan atau leher dapat merubah jarak konfigurasi gigi. Pergerakan rahang dan lidah seseorang juga berkontribusi dalam bentuk jejas yang terbentuk. Tergantung dari lokasi 


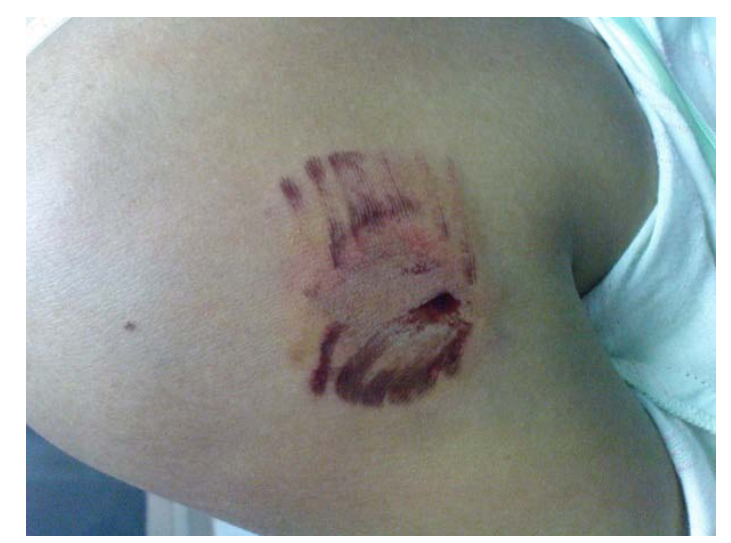

Gambar 3. Jejas gigitan yang terbentuk dengan pergerakan rahang pelaku atau anggota tubuh korban

gigitan, umumnya jejas gigitan dari salah satu rahang akan lebih jelas dibanding yang lain. Bila korban bergerak saat digigit, jejas gigitan juga akan memberi pola berbeda dengan pola yang terbentuk bila korban dalam kondisi diam (Gambar 3).

Waktu pembuatan cetakan gigi sejak terjadinya jejas gigitan juga amat memengaruhi akurasi cetakan gigi karena proses penyembuhan yang akan merubah bentuk jejas dan akhirnya memengaruhi model gigi yang akan dicocokan dengan cetakan gigi pelaku. ${ }^{15}$

Berbeda dengan DNA atau sidik jari, bentuk dan konfigurasi gigi seseorang dapat mengalami perubahan yang cukup besar dalam masa hidupnya, baik dengan bantuan dokter gigi, perawat gigi, tukang gigi atau peristiwa lain seperti benturan pada wajah yang menyebabkan perubahan bentuk dan konfigurasi gigi.

Proses penyakit seperti karies atau penyakit periodontal juga dapat merubah konfigurasi gigi, karenanya ketidakcocokan cetakan gigi atau foto gigi tidak serta merta menyingkirkan seseorang dari kemungkinan sebagai tersangka atau orang yang dicari dalam proses identifikasi tersebut. ${ }^{1,13}$

Alat bukti berupa analisis jejas gigitan yang akan digunakan sebagai dokumen medikolegal harus dipastikan dibuat oleh tim yang terdiri dari orang-orang yang memiliki kompetensi dan kewenangan yang tepat. Pemanfaatan analisis jejas gigitan oleh orang yang tidak berkompeten akan menyebabkan terjadinya kesalahan identifikasi pelaku, seperti yang terjadi pada kasus Steven Chaney tahun 1987. ${ }^{16}$

\section{SIMPULAN}

Sebesar 85,29\% jejas gigitan pada penelitian ini dapat dicocokkan dengan cetakan gigi tersangka namun ketidakcocokan pola gigi tidak secara otomatis menyingkirkan seseorang dari daftar tersangka. Banyak variabel seperti bergeraknya rahang penggigit atau anggota badan korban yang digigit, atau perubahan jejas akibat proses penyembuhan dan variabel lain yang harus dicermati kembali untuk menyingkirkan seseorang dari daftar tersangka.

Perlu disusun sebuah kriteria untuk menetapkan standar minimal komposisi jejas gigitan agar dapat dianalisis dan diinterpretasi sebagai alat bukti. Ketiadaan standar minimal di Indonesia dapat menyebabkan jejas gigitan yang tidak memenuhi syarat kemudian didokumentasi, dianalisis, serta diinterpretasi sebagai alat bukti sehingga menimbulkan kesalahan identifikasi pelaku atau korban. Distorsi dan kesulitan lain yang disampaikan pada tulisan ini perlu dijadikan bagian dari standar minimal analisis tersebut.

\section{Ucapan Terima Kasih}

Penghargaan yang setinggi-tingginya disampaikan kepada AKBP drg. Hendra Arifianto, SpKG, drg Diah Buana, dan rekan-rekan dokter gigi yang bertugas di RS Bhayangkara Tingkat III, Manado, yang selama ini bekerja sebagai tim forensik yang solid di RS Bhayangkara.

\section{Konflik Kepentingan}

Penulis menyatakan tidak terdapat konflik kepentingan dalam studi ini.

\section{DAFTAR PUSTAKA}

1. Verma AK, Kumar S, Rathore S, Pandey A. Role of dental expert in forensic odontology. National Journal of Maxillofacial Surgery. 2014;5(1):2-5.

2. Gopal KS, Anusha AV. Evaluation of accuracy of human bite marks on skin and an inanimate object: a forensic-based 
cross-sectional study. Int $\mathrm{J}$ Forensic Odontol. 2018;3(1):2-5.

3. Souviron R, Haller L. Bite mark evidence: bite mark analysis is not the same as bite mark comparison or matching or identification. J Law Biosci. 2017;4(3): 617-22.

4. Sharma G, Yadav M, Singh H, aggrawal AD, Sandhu R. Bite mark analysis - an important tool in crime investigation. Journal of Indian Academy of Forensic Medicine (JIAFM). 2006;28(2).:69-71.

5. Bowers CM. Forensic Dental Evidence: An Investigator's Handbook. Massachusetts: Elsevier Academic Press, 2004.

6. RS Bhayangkara tingkat III Manado. Profil RS Bhayangkara tingkat III Manado tahun 2019. Manado: RS Bhayangkara tingkat III Manado, 2019; p. 1-12.

7. Jain N, editor. Textbook of Forensic Odontology. New Delhi: Jaypee Brother, 2012; p. 10-42.

8. Vale GL. Dentistry, bite marks and the investigation of crime. J Calif Dent Assoc. 1996;24:29-34.

9. Malinda Y, Zakiawati D. Acquittance of bite mark identification procedures in forensic odontology. Padjajaran Journal of Dentistry.2015;7(3):166-71.

10. Fonseca RJ, Walker RV, Barber HD, Powers MP, Frost DE. Oral and Maxillofacial Trauma. USA: Elsevier Academic
Press, 2013; p. 628-30.

11. Lumente MA, Kristanto E, Siwu J. Keragaman kasus forensik klinik di RS Bhayangkara Tingkat III Manado dari sudut pandang SKDI 2012 periode Juli 2015-Juni 2016. e-CliniC. 2016;4(2): 51-6.

12. Saks MJ, Albright T, Bohan TL, Bierer BE, Bowers CM, et al. Forensic bitemark identification: weak foundations, exaggerated claims. J Law Biosci. 2016; 3(3): p.538-575.

13. Blackwell SA, Taylor RV, Gordon I, Oqleby CL, Tanijiri T, Yoshino M, et al. 3-D imaging and quantitative comparison of human dentitions and simulated bite marks. Int J Legal Med. 2007;121(1):917.

14. Danile MJ, Pazhani A. Accuracy of bite mark analysis from food substances: a comparative study. J Forensic Dent Sci. 2015;7(3):222-6.

15. Dogra TD, Rudra A. Lyon's Medical Jurisprudence and Toxicology (11th ed). Delhi: Delhi Law House, 2005; p.101822.

16. Possley M. Steven Chaney exonerations. The national registry of exonerations. 2019. Available from: https://www.law. umich.edu/special/exoneration/Pages/c asedetail.aspx. Posting Date: 2/14/2019. 